\title{
Effect of dietary phytate on phosphorus digestibility in dairy cows ${ }^{1}$
}

\author{
P. P. Ray, ${ }^{2}$ J. Jarrett, and K. F. Knowlton \\ Department of Dairy Science, Virginia Polytechnic Institute and State University, Blacksburg 24061
}

\begin{abstract}
The objective was to evaluate the effect of dietary phytate $\mathrm{P}(\mathrm{Pp})$ supply on ruminal and postruminal $\mathrm{Pp}$ digestion and net disappearance of $\mathrm{P}$ from the lower digestive tract of lactating cows. Six ruminally and ileally cannulated crossbred lactating cows were used in 2 incomplete Latin squares with four 21-d periods (17 $\mathrm{d}$ of diet adaptation, $4 \mathrm{~d}$ of total collection). Dietary treatments were low $\mathrm{Pp}$, medium $\mathrm{Pp}$, and high $\mathrm{Pp}$, and a high inorganic $\mathrm{P}(\mathrm{Pi})$ diet with the same total $\mathrm{P}$ content as the highest $\mathrm{Pp}$ diet but with $\mathrm{P}$ mostly from inorganic sources. The diets contained 0.10, 0.18, 0.29 , and $0.11 \% \mathrm{Pp}$ and $0.43,0.48,0.54$, and $0.53 \%$ total $\mathrm{P}$ on a dry matter basis, with cottonseed meal used to increase Pp content. Ytterbium-labeled corn silage and Co-EDTA were used as particulate and liquid phase markers to measure omasal and ileal digesta flow. Omasal and ileal digesta were collected every 6 $\mathrm{h}$ on $\mathrm{d} 20$ and 21 and rumen contents were collected on d 21. Samples were analyzed for total P (molybdovanadate yellow method), $\mathrm{Pi}$ (blue method), and $\mathrm{Pp}$ (high performance ion chromatography). Phytate $\mathrm{P}$ and total $\mathrm{P}$ intake increased linearly with increasing dietary Pp. Ruminal Pp disappearance also increased linearly with dietary $\mathrm{Pp}$ but the magnitude of change was small. Small intestinal net disappearance of $\mathrm{Pi}$ was not affected by dietary $\mathrm{Pp}$. Phytate $\mathrm{P}$ was hydrolyzed in the large intestine but its hydrolysis was not influenced by dietary $\mathrm{Pp}$. Net disappearance of $\mathrm{Pi}$ form the large intestine did not vary with dietary Pp. Dry matter digestibility decreased linearly with increasing dietary $\mathrm{Pp}$, as did apparent digestion of $\mathrm{P}$, and fecal $\mathrm{P}$ increased linearly. Dry matter digestibility was higher for high Pi than for high Pp, likely due to the effect of cottonseed meal in the latter diet. Replacing a portion of $\mathrm{Pp}$ with $\mathrm{Pi}$ resulted in decreased $\mathrm{P}$ excretion but this effect was confounded with increased fecal dry matter for the high-Pp (high-cottonseed meal) diet. In lactat-
\end{abstract}

\footnotetext{
Received June 19, 2012.

Accepted October 7, 2012.

${ }^{1}$ This project was supported by National Research Initiative Competitive Grant no. 2009-55206-05267 from the USDA Cooperative State Research, Education, and Extension Service. Author Ray received fellowship support from the John Lee Pratt Foundation.

${ }^{2}$ Corresponding author: drray@vt.edu
}

ing cows Pp digestibility was not negatively influenced by dietary $\mathrm{Pp}$ and fecal $\mathrm{P}$ excretion was regulated by dietary total $\mathrm{P}$ rather than by form of dietary $\mathrm{P}$.

Key words: phytate, digestibility, dairy cow

\section{INTRODUCTION}

Accurate prediction of $\mathrm{P}$ availability could allow new dietary $\mathrm{P}$ manipulation strategies to reduce $\mathrm{P}$ excretion without affecting production and performance of dairy cows. The digestibility of $\mathrm{P}$ is higher in inorganic $\mathrm{P}$ supplements than in grains and byproduct feed ingredients (Chicco et al., 1965; Witt and Owens, 1983), and digestibility of organic $\mathrm{P}$ in the latter types of feed may also vary. Phytate $\mathrm{P}(\mathbf{P} \mathbf{p})$ contributes the majority of $\mathrm{P}$ in grains and most of the byproduct feed ingredients (Eeckhout and Depaepe, 1994; Ravindran et al., 1994). Ruminants can utilize P from phytate because ruminal microorganisms are capable of synthesizing phytase enzyme, which can release a phosphate group from the phytate molecule (Nelson et al., 1976; Clark et al., 1986; Morse et al., 1992), but ruminal Pp hydrolysis is variable. It is influenced by the type of grain, processing of feed ingredients, and supplemental exogenous phytase enzyme (Park et al., 2000; Bravo et al., 2002; Kincaid et al., 2005). The variation in ruminal Pp hydrolysis may be due to the alteration in endogenous phytase activity (Yanke et al., 1998) or due to physical or chemical alterations of the phytate molecule.

Modern dairy rations contain large amounts of high-phytate grains and byproduct feed ingredients. Increased $\mathrm{Pp}$ intake together with high DMI may limit ruminal $\mathrm{Pp}$ hydrolysis by reducing the duration of Pp exposure to microbial phytase while increasing the amount of substrate (phytate). In addition, saturation of ruminal phytase activity may occur in high-grain (high-phytate) diets. High-grain diets also are associated with reduced secretion of saliva, possibly decreasing salivary $\mathrm{P}$ available for microbial use and for absorption in the small intestine (Scott and Buchan, 1985). Incomplete ruminal hydrolysis of $\mathrm{Pp}$ can be compensated only if large intestinal hydrolysis of remaining phytate occurs and if released inorganic $\mathrm{P}(\mathbf{P i})$ is absorbed from the large intestine. Little data are available on changes in ruminal and postruminal Pp hydrolysis with dietary Pp concentration in rumi- 
Table 1. Ingredient and nutrient composition of diets

\begin{tabular}{lcccc}
\hline & \multicolumn{3}{c}{ Diet $^{1}$} \\
\cline { 2 - 5 } Item & LPP & MPP & HPP & HPI \\
\hline Ingredient, \% of dietary DM & & & & \\
Corn silage & 46.1 & 45.6 & 45.2 & 45.8 \\
Grass hay & 9.42 & 9.33 & 9.25 & 9.36 \\
Corn, ground & 9.32 & 9.23 & 9.14 & 9.26 \\
Cottonseed meal & - & 12.5 & 24.7 & - \\
Soybean meal, 48\% & 14.1 & 7.00 & - & 14.0 \\
Beet pulp, dried & 9.63 & 7.16 & 4.73 & 9.57 \\
Cane molasses, dehydrated & 2.99 & 2.96 & 2.93 & 2.97 \\
Pro-Lak & 4.82 & 2.63 & 0.47 & 4.79 \\
Urea & 0.63 & 0.31 & - & 0.63 \\
Limestone & 0.92 & 1.25 & 1.54 & 0.91 \\
Vitamin-mineral mix & 2.10 & 2.08 & 2.06 & 2.08 \\
Monoammonium phosphate & - & - & & 0.65 \\
Nutrient & & & & \\
DM, \% & 56.2 & 54.0 & 54.5 & 54.1 \\
CP, \% of DM & 18.2 & 17.6 & 18.6 & 17.0 \\
NDF, \% of DM & 34.7 & 31.9 & 35.0 & 36.1 \\
ADF, \% of DM & 18.3 & 16.7 & 18.7 & 19.0 \\
Ca, \% of DM & 1.04 & 1.07 & 0.90 & 0.90 \\
P, \% of DM & 0.43 & 0.48 & 0.54 & 0.53 \\
Phytate P, \% of DM & 0.10 & 0.18 & 0.29 & 0.11 \\
\hline
\end{tabular}

${ }^{1} \mathrm{LPP}=$ low phytate $\mathrm{P}(\mathrm{Pp}) ; \mathrm{MPP}=$ medium Pp; HPP = high Pp; HPI = high inorganic $\mathrm{P}$.

${ }^{2}$ H. J. Baker \& Bro. Inc. (Sanford, NC).

${ }^{3}$ Contained 26,400 kIU of vitamin A, 8,800 kIU of vitamin D, and 44,000 IU of vitamin E per kilogram of DM; $37 \% \mathrm{Na} ; 60 \% \mathrm{Cl} ; 0.03 \% \mathrm{~K} ; 0.3 \% \mathrm{Mg} ; 14 \% \mathrm{~S}$; and $90 \mathrm{mg}$ of $\mathrm{Se} / \mathrm{kg}$.

nants. Therefore, the objective of this study was to investigate the effect of dietary $\mathrm{Pp}$ on ruminal and postruminal $\mathrm{P}$ digestibility in dairy cows.

\section{MATERIALS AND METHODS}

\section{Animals and Experimental Design}

Six crossbred [Swedish Red or Brown Swiss $\times$ (Holstein $\times$ Jersey)] first-lactation cows averaging $463 \mathrm{~kg}$ of BW and $90( \pm 35)$ DIM were used in 2 incomplete $4 \times 4$ Latin squares. To create incomplete squares, the bottom row from the first square and third row from the second square were removed. These animals were a subset of the 8 animals used in a previous study (Ray et al., 2012b). The cows were fitted surgically with a half T-type ileal cannula made of Tygon (5 to $6 \mathrm{~cm}$ anterior to the ileocecal junction) and a ruminal cannula (Bar Diamond Inc., Parma, ID). Ileal cannulas were cleaned every other day and checked daily for correct position.

During diet adaptation, cows were housed in a freestall barn with constant access to water and fed once daily at $1200 \mathrm{~h}$ in a Calan door system (American Calan Inc., Northwood, NH). Dietary treatments were low, medium, and high Pp (LPP, MPP, and HPP, respectively), and a high-Pi (HPI) diet with the same total $\mathrm{P}$ content as the HPP diet but with $\mathrm{P}$ mostly from inorganic sources. The diets contained 0.10, 0.18,
0.29 , and $0.11 \% \mathrm{Pp}$ and $0.43,0.48,0.54$, and $0.53 \%$ total $\mathrm{P}$ on DM basis (Table 1), with cottonseed meal (CSM) used to increase Pp content. Diets were formulated to meet or exceed NRC (2001) recommendations for all nutrients. Feed was offered ad libitum during diet adaptation.

After $15 \mathrm{~d}$ of diet adaptation, cows were moved to individual tiestalls in a metabolism barn for a 2-d barn acclimation period (d 16 and 17) followed by $4 \mathrm{~d}$ of total collection (d 18 to 21). While in the metabolism barn, cows were fed ad libitum 4 times daily at 0600, 1200,1800 , and $2400 \mathrm{~h}$ to minimize diurnal variation in digesta flow. Cows were milked twice daily at 0600 and 1800 h. On d 17 of each period, cows were fitted with urinary catheters for total collection of urine. Cows were observed for symptoms of infection, and rectal temperatures were recorded daily.

Ytterbium-labeled corn silage (Harvatine et al., 2002) and Co-EDTA (Udén et al., 1980) were used as particulate and liquid phase markers, respectively, to measure omasal and ileal digesta flow. Beginning on $\mathrm{d}$ 16 of each period, markers were dosed into the rumen before each feeding at a rate of $0.11 \mathrm{~g}$ of $\mathrm{Yb}$ or $\mathrm{Co} / \mathrm{cow}$ per day. All protocols and procedures were approved by the Virginia Tech Institutional Animal Care and Use Committee (Blacksburg).

The daily omasal and ileal passage of nutrient was calculated using the following equation: 


$$
\begin{gathered}
\text { Daily nutrient flow }(\mathrm{g} / \mathrm{d})= \\
\frac{\text { Nutrient concentration in digesta }(\mathrm{mg} / \mathrm{g})}{\text { Marker concentration in digesta }(\mathrm{mg} / \mathrm{g})} \\
\times \text { Daily marker dose }(\mathrm{g} / \mathrm{d}) .
\end{gathered}
$$

As others have observed, the recovery of marker in the feces was not complete and ranged from as low as 50 to $95 \%$ of expected daily dose of marker (g/d). In case of incomplete recovery of marker, total daily marker excreted was used in place of daily marker dose $(\mathrm{g} / \mathrm{d})$ in the equation.

\section{Sample Collection and Preparation}

Total mixed ration and feed refusals were collected daily from d 16 to 21 of each period. Total fecal collection was conducted for last $4 \mathrm{~d}$ of each period. Feces from each cow was blended daily and a representative sample (approximately $4 \mathrm{~kg}$ ) was collected. Total daily urine was collected into a 12-L jug surrounded by ice to prevent evaporation and a subsample was collected daily for each cow (Knowlton et al., 2010). All samples were stored at $-20^{\circ} \mathrm{C}$ immediately after collection.

On d 20 and 21, omasal and ileal samples were collected every $6 \mathrm{~h}$, with the collection time shifted by 2 $\mathrm{h}$ on the second day to get sample representative of every $4 \mathrm{~h}$ over a 24 -h period. Omasal contents were collected using an omasal sampler placed in the omasal orifice and attached to a vacuum pump (Huhtanen et al., 1997). Ileal digesta was collected through the ileal cannula. All samples were stored at $-20^{\circ} \mathrm{C}$ immediately following collection.

Rumen evacuation was conducted on the last day of each period. Rumen contents were weighed and 2 representative subsamples collected; then, contents were returned to the rumen. One subsample was stored at $-20^{\circ} \mathrm{C}$ immediately following collection and the other subsample was composited by period to isolate rumen microbes (Cecava et al., 1990). Briefly, $500 \mathrm{~mL}$ of saline was added to $1,500 \mathrm{~mL}$ of composited rumen contents and the mixture was blended in a Waring blender (Waring Products Inc., Torrington, CT) for 2 min. Blended rumen contents were strained through 4 layers of cheesecloth to yield a homogenized fluid with small particles. Strained fluid was centrifuged twice at $500 \times g$ for 20 and $10 \mathrm{~min}$. Pellets were discarded and the remaining supernatant was centrifuged at $8,000 \times$ $g$ for 20 and $10 \mathrm{~min}$ to capture the microbes in the pellet. Fresh isolated microbes were stored at $-80^{\circ} \mathrm{C}$ before being freeze dried (Genesis 25EL; VirTis, Stone Ridge, NY).

Frozen samples were later thawed and TMR, refusals, and omasal and ileal samples were composited by cow by period. Total mixed ration and refusals were oven dried (Wisconsin Oven; Memmert GmbH \& Co., Schwabach, Germany) at $55^{\circ} \mathrm{C}$ until constant dry weight was achieved. Rumen, ileal, and fecal samples were freeze dried (Genesis 25EL). Dried samples were ground through a Wiley mill (1-mm screen; Arthur H. Thomas Co., Philadelphia, PA) and then through a Z grinder (0.2-mm screen; ZM 100 USA; Retsch GmbH, Haan, Germany). Ground samples were stored in airtight containers.

Because of possible bias in collecting heterogeneous omasal samples, omasal contents were fractionated into fluid, small, and large particulate phases following the method described by Reynal and Broderick (2005). Briefly, omasal contents were strained through single-layer cheesecloth to separate large particles from fluid and small particles. Then fluid containing small particles was centrifuged at $1,000 \times g$ for $5 \mathrm{~min}$ to separate small particles from fluid. The 3 phases were freeze dried (Genesis 25EL). Dried small and large particulate phases were ground through a $\mathrm{Z}$ grinder (0.2-mm screen; ZM 100 USA; Retsch GmbH). Omasal fluid phases were ground using a freezer mill (SPEX 6850 Freezer Mill; SPEX CertiPrep Inc., Metuchen, $\mathrm{NJ}$ ) because of the hygroscopic nature of the material.

\section{Sample Analysis}

Dried ground TMR, feed refusals, and feces were analyzed for $\mathrm{N}$, total $\mathrm{P}$ (AOAC, 1984), and NDF and ADF sequentially (Van Soest et al., 1991). Feed samples were analyzed for Ca using inductively coupled plasma atomic emission spectroscopy (Ciros Vision model; Spectro Analytical Instruments Inc., Mahwah, NJ). Urine samples were analyzed for total P (AOAC, 1984). Omasal, ileal, and fecal samples were prepared for the analysis of $\mathrm{Yb}$ (Harvatine et al., 2002) and Co (Udén et al., 1980) and $\mathrm{Yb}$ and Co concentrations were determined using inductively coupled plasma atomic emission spectroscopy (Ciros Vision model; Spectro Analytical Instruments Inc.) at the Virginia Tech Soil Testing Laboratory (Blacksburg, VA). Milk samples were analyzed for fat, protein, lactose, SNF, milk urea $\mathrm{N}$, and SCC (DHIA laboratory Blacksburg, VA).

Total mixed ration, refusals, rumen, the 3 phases of omasal contents, and ileal and fecal samples were extracted with $0.5 \mathrm{M} \mathrm{HCl}$ (extracted for $4 \mathrm{~h}$ at ambient temperature and then centrifuged at $30,000 \times g$ for 20 min at $4^{\circ} \mathrm{C}$ ) and analyzed for Pi using the molybdenum blue method as described by Murphy and Riley (1958).

Feed samples were analyzed for inositol hexaphosphate (IP6; phytate) using the method developed by Ray et al. (2012a). Rumen contents, the 3 phases of omasal contents, and ileal and fecal samples were 
analyzed for IP6 and lower inositol phosphates (IP5, IP4, IP3, also known as lower IP) following the method described by Ray et al. (2012b). In brief, IP6 and lower IP were extracted from dried ground samples using 0.25 $M$ NaOH-0.05 $M$ EDTA and then centrifuged at 30,000 $\times g$ for $20 \mathrm{~min}$ at $4^{\circ} \mathrm{C}$. Alkaline extracts were acidified with $\mathrm{HCl}-\mathrm{HF}$ acid solution $(500 \mu \mathrm{L}$ of $6 \mathrm{M} \mathrm{HCl}$ and 1.2 $M \mathrm{HF}$ added to $5 \mathrm{~mL}$ sample extract) and stored overnight at $4^{\circ} \mathrm{C}$. After overnight storage, acidified extracts were centrifuged at $30,000 \times g$ for $20 \mathrm{~min}$ at $4^{\circ} \mathrm{C}$ and clear supernatants were collected and passed through a methanol-conditioned $\mathrm{C}_{18}$ column (Sep-Pak plus; Waters, MA) fitted with a $0.2-\mu \mathrm{m}$ ion chromatography (IC) membrane [polytetrafluoroethylene (PTFE) filter; IC Millex-LG; Millipore Corp., Billerica, MA].

Inositol hexaphosphate and lower IP in clear sample extracts were quantified by HPIC (Dionex ICS 3000 with a Dionex $4 \times 50$ IonPac AG7 guard column and a $4 \times 250 \mathrm{~mm}$ IonPac AS7 analytical column; Dionex Corp., Sunnyvale, CA) using pH 4 elution and postcolumn reaction detection (Rounds and Nielsen, 1993; Kwanyuen and Burton, 2005; Leytem et al., 2008). Phytate (IP6), IP5, IP4, and IP3 were eluted at 11.8, $10.5,8.9$, and $6.8 \mathrm{~min}$, respectively, with gradient elution (0.01 $M$ methylpiperazine and $0.01 M \mathrm{NaNO}_{3}-0.01$ $M$ methylpiperazine) at a flow rate of $1 \mathrm{~mL}$ per min. Eluted phytate and lower IP were detected using a UVvisible detector, with absorbance monitored at $500 \mathrm{~nm}$ after the derivatization reaction with Wade's reagent $\left(0.015 \% \mathrm{FeCl}_{3}+0.15 \%\right.$ sulfosalicylic acid solution $)$ in a postcolumn reactor.

\section{Statistical Analysis}

All intake, flow, and excretion data were analyzed using PROC GLIMMIX in SAS (SAS Institute, 2002). The model included square, diet, and period as fixed effects and cow as random effect. Polynomial contrasts were used to test the effect of increasing dietary Pp on intake, disappearance, and fecal excretion. Pre-planned contrast was used to compare HPP and HPI diets. Statistical significance was declared at $P<0.05$.

\section{RESULTS AND DISCUSSION}

\section{Nutrient Intake, Digestibility, and Milk Production and Composition}

Dry matter intake was not affected by either dietary Pp concentration or by the form of dietary P (Table 2 ). Total-tract digestibility of DM decreased linearly with increasing dietary $\mathrm{Pp}$ and was also lower in the HPP diet than in the HPI diet. This effect may be due to inclusion of CSM in the MPP and HPP diets (12.5 and $24.7 \%$ of dietary DM). The decrease in DM digestibility for CSM-supplemented diets was associated with reduced NDF digestibility. Fiber digestibility tended to decrease linearly $(P=0.06)$ with increasing dietary $\mathrm{Pp}$ and fiber digestibility was less in cows fed the HPP diet compared with cows fed the HPI diet. Others have observed decreased ruminal digestion of OM (Zinn et al., 1997), NDF, and N (Goetsch and Owens, 1985) with increased CSM content of diets for lactating cows, and this is usually associated with concomitant reductions in total-tract digestion. Postruminal digestion is less often affected by CSM content but postruminal NDF digestion was decreased in one study (Goetsch and Owens, 1985). Apparent digestibility of $\mathrm{N}$ decreased linearly with increasing dietary $\mathrm{Pp}$, likely because protein in CSM is relatively slowly degraded (Pires et al., 1997).

Milk and milk component yield and content were not affected by dietary $\mathrm{Pp}$ or dietary $\mathrm{P}$ form except that milk fat yield, content, and MUN showed a trend for a quadratic (milk fat yield $P=0.07$; milk fat content $P$ $=0.01)$ and linear $(P=0.06)$ relationship, respectively (Table 3). Fat yield was lower in cows fed MPP than in cows fed LPP or HPP diets. This aligns with the

Table 2. Effect of diet on nutrient intake and digestibility

\begin{tabular}{|c|c|c|c|c|c|c|c|c|}
\hline \multirow{2}{*}{ Item } & \multirow{2}{*}{\multicolumn{4}{|c|}{$\operatorname{Diet}^{1}$}} & \multirow{2}{*}{$\mathrm{SE}$} & \multicolumn{3}{|c|}{$P$-value } \\
\hline & & & & & & \multicolumn{2}{|c|}{ Dietary phytate } & $\begin{array}{c}\text { HPP vs } \\
\text { HPI }\end{array}$ \\
\hline DMI, $\mathrm{kg} / \mathrm{d}$ & 17.9 & 18.6 & 18.1 & 17.8 & 0.61 & 0.82 & 0.35 & 0.71 \\
\hline DM digestibility, ${ }^{2} \%$ & 69.6 & 65.8 & 64.5 & 68.9 & 0.96 & 0.0009 & 0.24 & 0.004 \\
\hline NDF intake, $\mathrm{kg} / \mathrm{d}$ & 5.75 & 5.48 & 6.24 & 6.23 & 0.33 & 0.26 & 0.19 & 0.98 \\
\hline $\mathrm{N}$ digestibility, ${ }^{2} \%$ & 71.7 & 64.6 & 63.2 & 67.4 & 1.9 & 0.005 & 0.25 & 0.11 \\
\hline
\end{tabular}

${ }^{1} \mathrm{LPP}=$ low phytate $\mathrm{P}(\mathrm{Pp}) ; \mathrm{MPP}=$ medium $\mathrm{Pp} ; \mathrm{HPP}=$ high $\mathrm{Pp} ; \mathrm{HPI}=$ high inorganic $\mathrm{P}$.

${ }^{2}$ Total-tract digestibility. 
Table 3. Effect of diet on milk yield and composition

\begin{tabular}{|c|c|c|c|c|c|c|c|c|}
\hline \multirow[b]{2}{*}{ Item } & \multicolumn{4}{|c|}{$\operatorname{Diet}^{1}$} & \multirow[b]{2}{*}{$\mathrm{SE}$} & \multicolumn{3}{|c|}{$P$-value } \\
\hline & LPP & MPP & $\mathrm{HPP}$ & HPI & & Linear & Quadratic & $\begin{array}{c}\text { HPP vs } \\
\text { HPI }\end{array}$ \\
\hline Milk yield, $\mathrm{kg} / \mathrm{d}$ & 33.0 & 32.6 & 32.8 & 34.0 & 1.08 & 0.84 & 0.79 & 0.41 \\
\hline Milk fat, $\mathrm{kg} / \mathrm{d}$ & 1.52 & 1.34 & 1.54 & 1.57 & 0.08 & 0.81 & 0.07 & 0.81 \\
\hline Milk fat, $\%$ & 4.59 & 4.17 & 4.71 & 4.56 & 0.15 & 0.55 & 0.01 & 0.48 \\
\hline Milk lactose, $\%$ & 4.86 & 4.87 & 4.85 & 4.87 & 0.04 & 0.94 & 0.77 & 0.78 \\
\hline $\mathrm{SNF}, \mathrm{kg} / \mathrm{d}$ & 3.03 & 2.99 & 3.02 & 3.13 & 0.10 & 0.97 & 0.76 & 0.42 \\
\hline $\mathrm{SNF}, \%$ & 9.19 & 9.19 & 9.22 & 9.24 & 0.07 & 0.75 & 0.82 & 0.82 \\
\hline MUN, mg/dL & 18.7 & 16.9 & 16.5 & 15.9 & 0.83 & 0.06 & 0.46 & 0.60 \\
\hline
\end{tabular}

${ }^{1} \mathrm{LPP}=$ low phytate $\mathrm{P}(\mathrm{Pp}) ; \mathrm{MPP}=$ medium $\mathrm{Pp} ; \mathrm{HPP}=$ high $\mathrm{Pp} ; \mathrm{HPI}=$ high inorganic $\mathrm{P}$

numerically lower NDF intake and digestibility in cows fed the MPP diet compared with LPP and HPP diets, but the ultimate cause of these effects is unclear.

\section{Phosphorus Intake, Flow, and Excretion}

Effect of Dietary Phytate. As planned, Pp intake increased linearly with increasing dietary Pp (Table 4) as did total $\mathrm{P}$ intake, but $\mathrm{Pi}$ intake decreased linearly with increasing dietary Pp. Rumen pool size of total P, $\mathrm{Pi}$, and $\mathrm{Pp}$ was not affected by dietary $\mathrm{Pp}$ (Table 5 ). Ruminal disappearance (\% of intake) of Pp increased linearly with increasing dietary $\mathrm{Pp}$. This increase in Pp digestibility was probably due to increased microbial phytase activity in the rumen. Phytase activity increased with increasing $\mathrm{Pp}$ in microbes isolated from the rumen (Yanke et al., 1998) and in a semicontinuous culture system fermentor (Godoy and Meschy, 2001). Although ruminal hydrolysis of dietary Pp was almost complete, others have reported that substantial amounts of Pp can escape the rumen (Park et al., 1999; Kincaid et al., 2005). The results of this study and previous studies showed a wide range (57 to $>90 \%$ ) of ruminal $\mathrm{Pp}$ hydrolysis, which varied with several factors such as type of feed ingredient, type of diet, and feed processing method (Konishi et al., 1999; Park et al., 1999; Ray et al., 2012b).

Omasal flow of total $\mathrm{P}$ was not affected by dietary Pp (Table 4). Although total $\mathrm{P}$ intake increased with increasing dietary $\mathrm{Pp}$, the large amount of salivary $\mathrm{P}$ entering the rumen nullified any difference in the rumen pool of total P (Scott and Buchan, 1985). Similarly, omasal flow of $\mathrm{Pi}$ and $\mathrm{Pp}$ were not influenced by dietary Pp. The flow of total P, Pi, and Pp to the ileum increased linearly with increasing dietary Pp (Table 4). These increases were due to increases in ileal DM flow; the concentration of total $\mathrm{P}, \mathrm{Pp}$, and $\mathrm{Pi}$ in ileal digesta did not vary. In one study with lactating Holstein cows, the effect of dietary $\mathrm{P}$ on apparent digestibility of $\mathrm{P}$ was confounded with the effect of diet of fecal DM (Wu, 2005). On average, small intestinal net disappearance of Pi was $71 \%$ of omasal $\mathrm{Pi}$ flow and was not influenced by dietary $\mathrm{Pp}$ or total $\mathrm{P}(75,70$, and $68 \%$ for LPP, $\mathrm{MPP}$, and HPP diets). Ileal flow of microbial $\mathrm{P}$ was not influenced by dietary $\mathrm{Pp}$ and ranged from 2.35 to $2.70 \mathrm{~g} / \mathrm{d}$.

In this study, Pp was degraded in the large intestine and net disappearance of $\mathrm{Pi}$ in the large intestine was observed $(8.4,12.3$, and $9.6 \%$ of ileal Pi flow for LPP, MPP, and HPP diets, respectively). Large intestinal Pp degradation was not influenced by dietary $\mathrm{Pp}$ and on average, $16 \%$ of ileal $\mathrm{Pp}$ flowing into the large intestine was degraded $(22.8,9.8,11.6$, and $21.4 \%$ of ileal $\mathrm{Pp}$ flow for LPP, MPP, HPP, and HPI diets, respectively). A similar extent of Pp degradation (19\% of Pp entering the large intestine) was observed in the large intestine of sheep (Park et al., 2002). Large intestinal Pp hydrolysis in the present study was likely due to microbial phytase activity in the large intestine, as was reported by others (Wise and Gilburt, 1982; Matsui et al., 1999). Similar microbial populations are found both in the rumen and the large intestine, and the presence of phytase activity in some bacterial strains isolated from the large intestine of ruminants would reinforce this conclusion (Hoover, 1978; Joseph and Raj, 2007). Inorganic $\mathrm{P}$ flowing into the large intestine or released from Pp degradation would be of nutritional significance if animals can absorb that $\mathrm{Pi}$ in the large intestine. Net disappearance of $\mathrm{Pi}$ in the large intestine as observed in this study and reported by other researchers indicated possible nutritional significance of large intestinal $\mathrm{P}$ digestion in ruminants (Ben-Ghedalia et al., 1975; Scharrer, 1985).

Average urinary $\mathrm{P}$ excretion was $0.26 \mathrm{~g} / \mathrm{d}$ and was not affected by dietary Pp. Microbial $\mathrm{P}$ in the feces ranged from 3.48 to $4.75 \mathrm{~g} / \mathrm{d}$ and was not affected by 
Table 4. Effect of diet on intake, omasal flow, ileal flow, and fecal excretion of $\mathrm{P}$, inorganic $\mathrm{P}(\mathrm{Pi})$, phytate $\mathrm{P}(\mathrm{Pp})$, and microbial $\mathrm{P}$ (Pm)

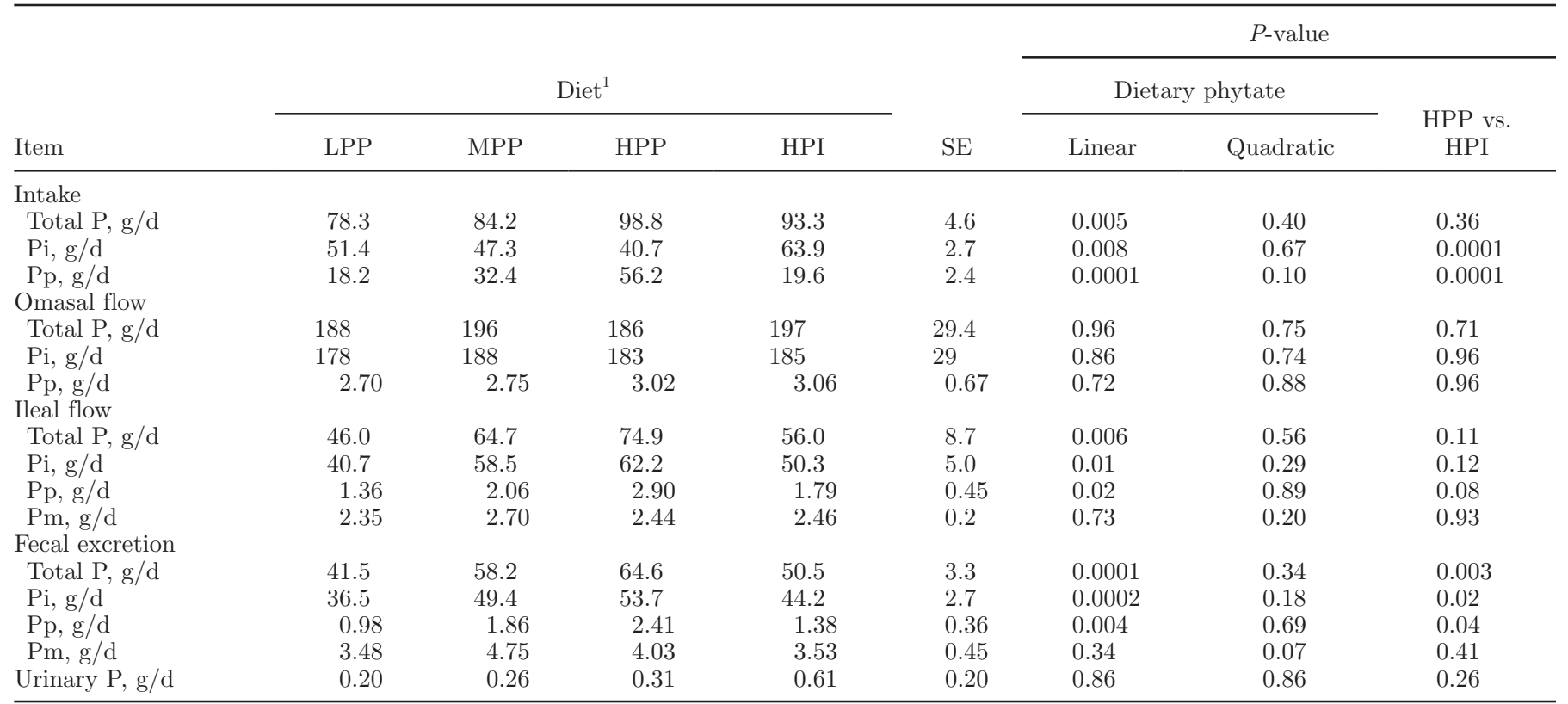

${ }^{1} \mathrm{LPP}=$ low $\mathrm{Pp} ; \mathrm{MPP}=$ medium Pp; HPP $=$ high Pp; HPI $=$ high Pi.

dietary Pp (Table 4). Fecal excretion of total P, Pi, and Pp increased linearly with increasing dietary Pp (Table 4). A key question is whether fecal excretion of these was caused by increased fecal DM excretion for MPP and HPP diets, by the effect of the form of dietary P, or both. The concentration of total $\mathrm{P}, \mathrm{Pp}$, and $\mathrm{Pi}$ in feces increased linearly with increasing dietary $\mathrm{Pp}$ and, thus, we conclude that dietary $\mathrm{P}$ directly influenced fecal P excretion, independent of the effect of CSM on fecal DM excretion. This still leaves open the question of whether the effect of dietary $\mathrm{P}$ was the amount of dietary $\mathrm{P}$ or form, as these are confounded in the first 3 diets. Several authors have shown increased fecal $\mathrm{P}$ with addition of $\mathrm{Pi}$ to the diet (Wu et al., 2000; Knowlton and Herbein, 2002). Almost complete ruminal degradation of $\mathrm{Pp}$ in this study eliminated any possible effect of dietary $\mathrm{Pp}$ on postruminal $\mathrm{P}$ digestion and fecal P excretion. Similar to the observation by Dou et al. (2002), the increment in fecal $\mathrm{P}$ was associated with increased fecal $\mathrm{Pi}$ in the current study. Therefore, it can be concluded that $\mathrm{Pi}$ was available in the digestive tract and the degradation of the complex form of $\mathrm{P}$ was not affected by dietary Pp. The linear decrease in apparent digestibility of $\mathrm{P}$ with increasing dietary Pp or P $(47,37$, and $32 \%$ of $\mathrm{P}$ intake for LPP, MPP, and HPP diets, respectively) was in agreement with the results in previous studies (Wu et al., 2001; Knowlton and Herbein, 2002).

Effect of Dietary $\boldsymbol{P}$ Form. As intended, total P intake was not different between the HPP and the HPI diet (Table 4). Phytate P intake was higher and Pi intake was lower for the HPP diet than for the HPI diet.

The rumen pool size of total $\mathrm{P}$ was higher in the HPP group than in the HPI group but form of dietary $\mathrm{P}$ did not influence the rumen pool size of $\mathrm{Pp}$ and $\mathrm{Pi}$ (Table 5). Ruminal disappearance (\% of intake) of $\mathrm{Pp}$

Table 5. Effect of diet on rumen pool size of $\mathrm{P}$, inorganic $\mathrm{P}(\mathrm{Pi})$, and phytate $\mathrm{P}(\mathrm{Pp})$ and ruminal disappearance of $\mathrm{Pp}$

\begin{tabular}{|c|c|c|c|c|c|c|c|c|}
\hline \multirow[b]{3}{*}{ Item } & \multirow{2}{*}{\multicolumn{4}{|c|}{$\operatorname{Diet}^{1}$}} & \multirow[b]{3}{*}{$\mathrm{SE}$} & \multicolumn{3}{|c|}{$P$-value } \\
\hline & & & & & & \multicolumn{2}{|c|}{ Dietary phytate } & \multirow{2}{*}{$\begin{array}{c}\text { HPP vs. } \\
\text { HPI }\end{array}$} \\
\hline & LPP & MPP & HPP & HPI & & Linear & Quadratic & \\
\hline \multicolumn{9}{|l|}{ Rumen pool } \\
\hline Total P, g & 66.0 & 69.3 & 70.6 & 53.9 & 3.84 & 0.34 & 0.80 & 0.006 \\
\hline $\mathrm{Pi}, \mathrm{g}$ & 57.6 & 60.5 & 61.4 & 51.1 & 4.8 & 0.53 & 0.84 & 0.13 \\
\hline
\end{tabular}

${ }^{1} \mathrm{LPP}=$ low $\mathrm{Pp} ; \mathrm{MPP}=$ medium Pp; HPP $=$ high Pp; HPI = high Pi. 
was higher for the HPP diet than for the HPI diet. The larger total $\mathrm{P}$ pool in the rumen of cows fed the HPP diet was probably due to the smaller ruminal DM pool in the HPI diet compared with the HPP diet because ruminal total $\mathrm{P}$ concentration was not affected by dietary $\mathrm{P}$ form. Moreover, the initial pool of the readily soluble fraction of total $\mathrm{P}$ (i.e., Pi) was higher in the HPI diet compared with the HPP diet and a portion of $\mathrm{Pi}$ was probably transported at faster rate across the rumen wall (Breves et al., 1988). Increased ruminal Pp digestibility for the HPP diet was likely due to the high phytase activity in the presence of HPP. Another possible explanation could be the negative influence, if any, of HPI on the production and activity of microbial phytase as observed in different species of Aspergillus and several strains and varieties within the same species (Shieh and Ware, 1968). But this explanation may not be applicable in case of microbial phytase synthesis in the rumen because phytase activity in the rumen is primarily of bacterial origin and bacterial phytase synthesis is cell associated and independent of Pi concentration, unlike extracellular phytase in Aspergillus spp. (Yanke et al., 1998). The question can then be raised about the physiological significance of expressing the enzyme phytase by rumen microbes, given that sufficient $\mathrm{Pi}$ is always available for the microbes to use for their metabolism.

Omasal flow of total P, Pp, and Pi was not affected by form of dietary P (Table 4). Similarly, total P, Pp, and $\mathrm{Pi}$ flow to the ileum was not different between the HPP and HPI diets. But ileal flow of Pp tended to be higher $(P=0.08)$ in the HPP diet than in the HPI diet. Ileal flow of microbial $\mathrm{P}$ was not affected by dietary $\mathrm{P}$ form $(2.46 \mathrm{~g} / \mathrm{d}$ for HPP vs. $2.44 \mathrm{~g} / \mathrm{d}$ for HPI; Table 4). Net disappearance of $\mathrm{Pi}$ from the small intestine was not influenced by form of dietary $\mathrm{P}$ and was 68 and $71 \%$ of omasal Pi flow for the HPP and HPI diets, respectively. Large intestinal $\mathrm{Pp}$ disappearance was not different between the HPP and HPI diets (11.6 vs. $21.4 \%$ of ileal $\mathrm{Pp}$ flow, respectively). Unchanged large intestinal $\mathrm{Pp}$ disappearance with different amounts of $\mathrm{Pp}$ entering the large intestine confirmed that large intestinal Pp degradability was constant. In this study, no effect of replacing a portion of dietary $\mathrm{Pp}$ with $\mathrm{Pi}$ on small intestinal disappearance of $\mathrm{Pi}$ was similar to the observation that small intestinal net disappearance of $\mathrm{Pi}$ did not vary with increasing dietary $\mathrm{Pp}$ or total $\mathrm{P}$. Bravo et al. (2003) reported that when the range of dietary $\mathrm{P}$ was 0.25 to $0.50 \%$ (DM basis), the $\mathrm{P}$ absorption coefficient appeared to be constant and independent of dietary $\mathrm{P}$ supply.

As was not the case for ileal flow, fecal excretion of total P, Pp, and Pi was less for the HPI diet than for the HPP diet (Table 4). Form of dietary P did not influence fecal excretion of microbial P. Total-tract P digestibility was lower in the HPP diet than in the HPI diet (32 vs. $45 \%$ of $\mathrm{P}$ intake, respectively). Bravo et al. (2003) mentioned that $\mathrm{Pp}$ appeared as one of the factors affecting $\mathrm{P}$ digestion when the authors used a modeling approach to evaluate the effect of different variables on $\mathrm{P}$ digestibility. The concentration of total and other forms of $\mathrm{P}$ in fecal DM did not vary with dietary $\mathrm{P}$ form and fecal DM was higher for the HPP diet than for the HPI diet. We can speculate that the effect of dietary $\mathrm{P}$ form on fecal $\mathrm{P}$ excretion was partially, if not completely, influenced by fecal DM excretion.

\section{CONCLUSIONS}

In lactating cows, ruminal and post-ruminal digestion of $\mathrm{P}$ was related more to total dietary $\mathrm{P}$ rather than form of dietary P. This experiment supports the conventional wisdom that fecal $\mathrm{P}$ excretion increases with increasing dietary $\mathrm{P}$ intake. The rumen was the primary site of $\mathrm{Pp}$ hydrolysis in ruminants. No negative influence of increasing dietary $\mathrm{Pp}$ on ruminal $\mathrm{Pp}$ hydrolysis and almost complete Pp hydrolysis in the rumen indicated that ruminal phytase activity was not saturated by increasing dietary Pp (substrate). Large intestinal digestion of $\mathrm{Pp}$ and net disappearance of $\mathrm{Pi}$ were not affected by dietary $\mathrm{Pp}$ or by dietary $\mathrm{P}$ form and indicated that a fixed large intestinal $\mathrm{Pp}$ digestion and $\mathrm{Pi}$ absorption coefficient can be used in the modeling approach to estimate $\mathrm{P}$ availability.

\section{REFERENCES}

AOAC (Association of Official Analytical Chemists). 1984. Official Methods of Analysis. 14th ed. AOAC, Washington, DC.

Ben-Ghedalia, D., H. Tagari, S. Zamwel, and A. Bondi. 1975. Solubility and net exchange of calcium, magnesium and phosphorus in digesta flowing along the gut of the sheep. Br. J. Nutr. 33:87-94.

Bravo, D., F. Meschy, C. Bogaert, and D. Sauvant. 2002. Effects of fungal phytase addition, formaldehyde treatment and dietary concentrate content on ruminal phosphorus availability. Anim. Feed Sci. Technol. 99:73-95.

Bravo, D., F. Meschy, C. Bogaert, and D. Sauvant. 2003. Phosphorus availability of oilseed meals determined by the apparent faecal digestibility technique. Anim. Feed Sci. Technol. 108:43-60.

Breves, G., H. Höller, P. Packheiser, G. Gäbel, and H. Martens. 1988. Flux of inorganic phosphate across the sheep rumen wall in vivo and in vitro. Q. J. Exp. Physiol. 73:343-351.

Cecava, M. J., N. R. Merchen, L. C. Gay, and L. L. Berger. 1990. Composition of ruminal bacteria harvested from steers as influenced by dietary energy-level, feeding frequency, and isolation techniques. J. Dairy Sci. 73:2480-2488.

Chicco, C. F., C. B. Ammerman, J. E. Moore, P. A. van Walleghem, L. R. Arrington, and R. L. Shirley. 1965. Utilization of inorganic ortho-, meta- and pyrophosphates by lambs and by cellulolytic rumen microorganisms in vitro. J. Anim. Sci. 24:355-363.

Clark, W. D., J. E. Wohlt, R. L. Gilbreath, and P. K. Zajac. 1986. Phytate phosphorus intake and disappearance in the gastrointestinal tract of high producing dairy cows. J. Dairy Sci. 69:3151-3155.

Dou, Z., K. F. Knowlton, R. A. Kohn, L. D. Satter, Z. Wu, G. Zhang, J. D. Toth, and J. D. Ferguson. 2002. Phosphorus characteristics in dairy feces affected by diets. J. Environ. Qual. 31:2058-2065. 
Eeckhout, W., and M. De Paepe. 1994. Total phosphorus, phytatephosphorus and phytase activity in plant feedstuffs. Anim. Feed Sci. Technol. 47:19-29.

Godoy, S., and F. Meschy. 2001. Utilisation of phytate phosphorus by rumen bacteria in a semi-continuous culture system (RUSITEC) in lactating goats fed on different forage to concentrate ratios. Reprod. Nutr. Dev. 41:259-265.

Goetsch, A. L., and F. N. Owens. 1985. The effects of commercial processing method of cottonseed meal on site and extent of digestion in cattle. J. Anim. Sci. 60:803-813.

Harvatine, D. I., J. E. Winkler, M. Devant-Guille, J. L. Firkins, N. R. St-Pierre, B. S. Oldick, and M. L. Eastridge. 2002. Whole linted cottonseed as a forage substitute: Fiber effectiveness and digestion kinetics. J. Dairy Sci. 85:1988-1999.

Hoover, W. H. 1978. Digestion and absorption in hindgut of ruminants. J. Anim. Sci. 46:1789-1799.

Huhtanen, P., P. G. Brotz, and L. D. Satter. 1997. Omasal sampling technique for assessing fermentative digestion in the forestomach of dairy cows. J. Anim. Sci. 75:1380-1392.

Joseph, I., and R. P. Raj. 2007. Isolation and characterization of phytase producing Bacillus strains from mangrove ecosystem. J. Mar. Biol. Assoc. India 49:177-182.

Kincaid, R. L., D. K. Garikipati, T. D. Nennich, and J. H. Harrison. 2005. Effect of grain source and exogenous phytase on phosphorus digestibility in dairy cows. J. Dairy Sci. 88:2893-2902.

Knowlton, K. F., and J. H. Herbein. 2002. Phosphorus partitioning during early lactation in dairy cows fed diets varying in phosphorus content. J. Dairy Sci. 85:1227-1236.

Knowlton, K. F., M. L. McGilliard, Z. Zhao, K. G. Hall, W. Mims, and M. D. Hanigan. 2010. Effective nitrogen preservation during urine collection from Holstein heifers fed diets with high or low protein content. J. Dairy Sci. 93:323-329.

Konishi, C., T. Matsui, W. Park, H. Yano, and F. Yano. 1999. Heat treatment of soybean meal and rapeseed meal suppresses rumen degradation of phytate phosphorus in sheep. Anim. Feed Sci. Technol. 80:115-122.

Kwanyuen, P., and J. W. Burton. 2005. A simple and rapid procedure for phytate determination in soybeans and soy products. J. Am. Oil Chem. Soc. 82:81-85.

Leytem, A. B., P. Kwanyuen, P. W. Plumstead, R. O. Maguire, and J Brake. 2008. Evaluation of phosphorus characterization in broiler ileal digesta, manure, and litter samples: ${ }^{31} \mathrm{P}$ NMR vs. HPLC. J. Environ. Qual. 37:494-500.

Matsui, T., Y. Murakami, H. Yano, H. Fujikawa, T. Osawa, and Y. Asai. 1999. Phytate and phosphorus movements in the digestive tract of horses. Equine Vet. J. Suppl. 30:505-507.

Morse, D., H. H. Head, and C. J. Wilcox. 1992. Disappearance of phosphorus in phytate from concentrates in vitro and from rations fed to lactating dairy cows. J. Dairy Sci. 75:1979-1986.

Murphy, J., and J. P. Riley. 1958. A single-solution method for determination of soluble phosphate in sea water. J. Mar. Biol. Assoc. U. K. 37:9-14.

Nelson, T. S., L. B. Daniels, J. R. Hall, and L. G. Shields. 1976. Hydrolysis of natural phytate phosphorus in digestive-tract of calves. J. Anim. Sci. 42:1509-1512.

NRC. 2001. Nutrient Requirements of Dairy Cattle. 7th rev. ed. Natl. Acad. Press, Washington, DC.

Park, W. Y., T. Matsui, C. Konishi, S. W. Kim, F. Yano, and H. Yano. 1999. Formaldehyde treatment suppresses ruminal degradation of phytate in soyabean meal and rapeseed meal. Br. J. Nutr. 81:467-471.
Park, W. Y., T. Matsui, F. Yano, and H. Yano. 2000. Heat treatment of rapeseed meal increases phytate flow into the duodenum of sheep. Anim. Feed Sci. Technol. 88:31-37.

Park, W.-Y., T. Matsui, and H. Yano. 2002. Post-ruminal phytate degradation in sheep. Anim. Feed Sci. Technol. 101:55-60.

Pires, A. V., M. L. Eastridge, J. L. Firkins, and Y. C. Lin. 1997. Effects of heat treatment and physical processing of cottonseed on nutrient digestibility and production performance by lactating cows. J. Dairy Sci. 80:1685-1694.

Ravindran, V., G. Ravindran, and S. Sivalogan. 1994. Total and phytate phosphorus contents of various foods and feedstuffs of plant origin. Food Chem. 50:133-136.

Ray, P. P., C. Shang, and K. F. Knowlton. 2012a. Quantifying phytate in dairy digesta and feces: Alkaline extraction and high-performance ion chromatography. J. Dairy Sci. 95:3248-3258.

Ray, P. P., C. Shang, R. E. Pearson, and K. F. Knowlton. 2012b. Disappearance of infused phytate from the large intestine of dairy heifers. J. Dairy Sci. 95:5927-5935.

Reynal, S. M., and G. A. Broderick. 2005. Effect of dietary level of rumen-degraded protein on production and nitrogen metabolism in lactating dairy cows. J. Dairy Sci. 88:4045-4064.

Rounds, M. A., and S. S. Nielsen. 1993. Anion-exchange high-performance liquid-chromatography with post-column detection for the analysis of phytic acid and other inositol phosphates. J. Chromatogr. A 653:148-152.

SAS Institute. 2002. SAS User's Guide: Statistics. Version 9.2. SAS Inst. Inc., Cary, NC

Scharrer, E. 1985. Phosphate absorption at different intestinal sites in the developing lamb. Q. J. Exp. Physiol. 70:615-621.

Scott, D., and W. Buchan. 1985. The effects of feeding either roughage or concentrate diets on salivary phosphorus secretion, net intestinal phosphorus absorption and urinary phosphorus excretion in the sheep. Q. J. Exp. Physiol. 70:365-375.

Shieh, T. R., and J. H. Ware. 1968. Survey of microorganism for the production of extracellular phytase. Appl. Microbiol. 16:13481351.

Udén, P., P. E. Colucci, and P. J. Van Soest. 1980. Investigation of chromium, cerium and cobalt as markers in digesta. Rate of passage studies. J. Sci. Food Agric. 31:625-632.

Van Soest, P. J., J. B. Robertson, and B. A. Lewis. 1991. Methods for dietary fiber, neutral detergent fiber, and nonstarch polysaccharides in relation to animal nutrition. J. Dairy Sci. 74:3583-3597.

Wise, A., and D. J. Gilburt. 1982. Phytate hydrolysis by germfree and conventional rats. Appl. Environ. Microbiol. 43:753-756.

Witt, K. E., and F. N. Owens. 1983. Phosphorus: Ruminal availability and effects on digestion. J. Anim. Sci. 56:930-937.

Wu, Z. 2005. Utilization of phosphorus in lactating cows fed varying amounts of phosphorus and sources of fiber. J. Dairy Sci. 88:2850-2859.

Wu, Z., L. D. Satter, A. J. Blohowiak, R. H. Stauffacher, and J. H. Wilson. 2001. Milk production, estimated phosphorus excretion, and bone characteristics of dairy cows fed different amounts of phosphorus for two or three years. J. Dairy Sci. 84:1738-1748.

Wu, Z.. L. D. Satter, and R. Sojo. 2000. Milk production, reproductive performance, and fecal excretion of phosphorus by dairy cows fed three amounts of phosphorus. J. Dairy Sci. 83:1028-1041.

Yanke, L. J., H. D. Bae, L. B. Selinger, and K.-J. Cheng. 1998. Phytase activity of anaerobic ruminal bacteria. Microbiology 144:15651573.

Zinn, R. A., M. Montano, E. Alvarez, and Y. Shen. 1997. Feeding value of cottonseed meal for feedlot cattle. J. Anim. Sci. 75:2317-2322. 